\title{
PENGARUH PUBLIC SERVICE MOTIVATION DAN KEPUASAN KERJA TERHADAP KINERJA PEGAWAI
}

\author{
Al Asy Ari Adnan Hakim ${ }^{1}$, Nirsrina Hamid ${ }^{2}$ \\ ${ }^{1,2}$ Fakultas Ekonomi dan Bisnis Islam, Universitas Muhammadiyah Kendari \\ Email: alasyariadnanhakim@febi.umkendari.ac.id
}

\section{A R T I C L E I N F O}

Article History:

Received: 26 January 2021

Revised: 09 May 2021

Accepted: 24 May 2021

Keywords:

Public Service Motivation;

Kepuasan Kerja;

Kinerja Pegawai

\begin{abstract}
A B S T RA C T
Penelitian ini bertujuan untuk mengetahui dan menganalisis pengaruh public service motivation dan kepuasan kerja terhadap kinerja pegawai di kantor catatan sipil (Capil) Kabupaten Konawe Selatan. Penelitian ini merupakan penelitian kuantitatif dengan mengambil sampel pada 65 pegawai non PNS pada Kantor Capil Kabupaten Konawe Selatan. Metode analisis data yang digunakan adalah analisis regersi linear berganda. Berdasarkan hasil penelitian ditemukan bahwa public service motivation dan kepuasan kerja secara simultan berpengaruh signifikan terhadap kinerja pegawai. Hal ini berarti bahwa setiap adanya peningkatan yang terjadi pada public service motivation dan kepuasan kerja, maka akan memberikan dampak terhadap semakin tingginya kinerja pegawai. Public service motivation secara parsial berpengaruh positif signifikan terhadap kinerja pegawai. Hal ini berarti bahwa kinerja pegawai yang lebih baik dapat ditingkatkan dengan adanya peranan public service motivation. Kemudian, kepuasan kerja juga secara parsial berpengaruh positif signifikan terhadap kinerja pegawai. Hal ini berarti bahwa kinerja pegawai yang lebih baik dapat ditingkatkan dengan adanya peranan kepuasan kerja pegawai.
\end{abstract}

\section{Pendahuluan}

Masalah pelayanan publik yang terjadi di Indonesia menjadi salah satu fenomena terbesar di negara kita. Ditandai dengan semakin rendahnya kepercayaan masyarakat dan stigma yang kurang baik terhadap birokrasi publik. Pemerintah yang di dalamnya terdapat birokrasi seharusnya bertugas melayani masyarakat dengan mudah tetapi sebaliknya dipersulit, cepat tetapi menghambat, sehingga masyarakat malas berurusan dengan birokrasi.

Untuk mengatasi masalah pelayanan publik yang buruk ini, maka perlu dilakukan reformasi birokrasi ditubuh pemerintah dalam rangka meningkatkan kualitas pelayanan pada masyarakat dan mewujudkan good governance. Buruknya citra dan kinerja pemerintah tidak terlepas dari peran serta individu-individu yang terlibat dalam pelayanan publik (aparat pemerintah). Kim (2004) mengemukakan bahwa faktor individu merupakan prediktor yang penting bagi kinerja organisasi pemerintahan. Oleh sebab itu, guna meningkatkan kinerja organisasi pemerintahan, maka kinerja individual (yang diwakili dengan aparat pemerintah) juga harus ditingkatkan.

Hal ini sejalan yang diuraikan oleh Elsiyana (2014) yang mengemukakan bahwa berkaitan dengan pelayanan public saat ini, masyarakat menuntut agar segenap aparatur negara dapat 
mewujudkan administrasi negara yang mampu mendukung kelancaran dalam pelaksanaan tugas dan fungsi penyelengaraan pemerintahan negara, pembangunan dan pelayanan dengan berdasarkan prinsip-prinsip tata kepemerintahan yang baik. Di samping alasan tersebut, perbaikan dan peningkatan kemampuan dari pada pegawai negeri sipil dewasa ini semakin menjadi pusat perhatian karena fungsinya yang strategis dalam memberikan pelayanan kepada masyarakat.

Kebutuhan terciptanya para pegawai negeri sipil yang berkualitas, efisien dan profesional semakin dirasakan sejalan dengan perubahanperubahan yang terjadi sebagai hasil pembangunan dan dari perubahan eksternal pada tingkat regional dan global. Dominannya posisi dan peranan dari pegawai dalam pemberian pelayanan kepada masyarakat, hal ini tentu saja mensyaratkan agar setiap pegawai negeri sipil harus memiliki motivasi.

Salah satu motivasi yang harus dimiliki adalah motivasi dalam bentuk public service motivation (PSM) dimana motivasi ini mencakup kepercayaan, nilai dan sikap yang melampaui kepentingan pribadi dan kepentingan organisasi, mendorong seorang pekerja atau pegawai untuk berbuat baik kepada orang lain dan menyumbangkan darma baktinya kepada kesejahteraan organisasi dan masyarakat (Perry dan Annie, 2008). Artinya, motivasi pelayanan publik yang positif tentu saja akan melahirkan pekerja atau pegawai yang kompeten dan berdedikasi tinggi terhadap tugas dan kewajibannya, serta dapat meningkatkan prestasi kerja.

Public service motivation sebagai kecenderungan seseorang individu merespon motif yang secara unik dan biasanya terdapat dalam institusi-institusi publik merujuk pada kebutuhan psikologis. Lebih lanjut, Perry dan Wise (1990) menunjukkan bahwa jika dibandingkan dengan karyawan di sektor privat, karyawan yang bekerja di sektor publik lebih menitik beratkan pada nilai-nilai penghargaan (reward) intrinsik dan manfaat pekerjaan ketika melayani masyarakat dan kepentingan publik.

Dalam faktanya khususnya pada organisasi publik tanpa terkecuali pada kantor catatan sipil (Capil) Konawe Selatan, tidak semua dari pegawai memiliki public service motivation yang baik, meskipun jika dilihat dari kewajiban dan tanggungjawabnya yakni setiap pegawai dituntut untuk harus melayani masyarakat dan kepentingan publik secara maksimal tanpa adanya orientasi lain selain dari orientasi untuk tolong menolong dan orientasi pelayanan.

Adanya kecenderungan yang terjadi pada pegawai kantor Capil Konawe Selatan dalam pemberian pelayanannya belum sepenuhnya maksimal. Dimana pegawai cenderung tidak ramah dalam memberikan pelayanan, respon yang didapatkan dari pegawai atas pelayanan yang diberikan tidak terlalu baik, serta masih adanya beberapa kondisi dari pegawai yang mau untuk membantu dalam memberikan pelayanan jika didasarkan adanya orientasi ekonomis yang diberikan.

Perlu disadari pula bahwa pada kantor Capil Konawe Selatan, pegawai yang bekerja masih lebih banyak didominasi oleh pegawai yang berstatus dalam kategori non-PNS. Jika ditinjau dari antara hak dan kewajiban pegawai-pegawai yang berada dalam kategori Non PNS ini, maka dapat dikatakan bahwa adanya ketidakseimbangan yang terjadi antara tuntutan kewajiban dan hak yang didapatkan oleh Pegawai non-PNS. Seperti halnya hakhak pegawai dalam memperoleh gaji yang layak atau setara dengan UMR yang ditentukan. Padahal jika dilihat dari sisi tanggungjawabnya, antara pegawai PNS dan non-PNS, maka dapat terlihat bahwa tidak ada perbedaan kewajiban diantaranya. Sehingga hal ini dimungkinkan juga terjadi disebabkan adanya kepuasan kerja yang rendah dari pegawai non-PNS.

Kepuasan kerja pegawai merupakan hal yang turut mempengaruhi kinerja aparat pemerintah. Parvin dan Kabir (2011) menyatakan kepuasan kerja menggambarkan bagaimana perasaan individu terhadap pekerjaannya. Berbagai teori tentang kepuasan kerja juga telah dikembangkan oleh para psikolog yang cenderung menetapkan derajat yang berbeda bagi sumber kepuasan, yang dapat diklasifikasikan mejadi kepuasan kerja yang bersifat intrinsik dan kepuasan kerja yang bersifat ekstrinsik.

Para pegawai di sektor privat (swasta) biasanya lebih sering terfokus kepada kepuasan kerja yang bersifat ekstrinsik, seperti 
gaji yang tinggi, tunjangan, jaminan sosial, promosi, dan ganjaran lainnya yang bersifat materil. Kepuasan kerja yang bersifat ekstrinsik tentunya juga harus tetap mendapat perhatian pemerintah terhadap pegawai sektor publik karena mereka bekerja juga untuk mencari kesejahteraan dalam hidupnya.

Namun secara umum dapat dipahami bahwa para pegawai di sektor publik seharusnya lebih mementingkan kepusan kerja yang bersifat intrinsik, seperti penyelesaian tugas, pencapaian kerja, prestasi kerja, otonomi dan pengembangan diri. Karena kepuasan kerja yang hakiki seorang karyawan sektor publik adalah ketika mereka dapat memberikan kontribusi terhadap organisainya dan dapat memberikan pelayanan yang maksimal dan profesional kepada masyarakat sehingga menimbulkan kepuasan tersendiri dalam bentuk kepuasan batin .

Sejalan dengan dampak akibat dari buruknya public service motivation dan kepuasan kerja pegawai tersebut, capaian kinerja pegawai yang dihasilkan secara faktanya belum dapat dikatakan baik. Tingkat perhatian dan ketelitian pegawai atas tugas dan tanggungjawabnya dinilai masih belum sepenuhnya baik. Hal ini terbukti dari hasil kerja pegawai atas pembuatan KTP, KK dan Akta Kelahiran yang sering kali masih keliru dan atau belum terdapat database kependudukan, jangka waktu pembuatan KTP, KK dan Akta Kelahiran yang memakan waktu lebih dari 1 bulan. Selain itu adanya pula permasalahan yang terjadi pada ketepatan waktu kerja dari pegawai yang masih rendah, kurang mampunya pegawai dalam berdapatasi dengan lingkungan baru dan kerjasama antar karyawan yang dinilai masih rendah.

Bertitik tolak pada fenomena tersebut maka peneliti tertarik untuk mengkaji dan menganalisis secara lebih mendalam mengenai pengaruh public service motivation dan kepuasan kerja terhadap kinerja pegawai.

\section{Tinjauan Pustaka dan Pengembangan Hipotesis}

\subsection{Public Service Motivation}

Public Service Motivation (PSM) adalah salah satu faktor yang turut mempengaruhi kinerja individu pegawai sektor publik. Teori ini diperkenalkan oleh Perry dan Wise (1990).
Keduanya mendefinisikan PSM sebagai kecenderungan seseorang individu merespon motif yang secara unik dan biasanya terdapat dalam institusi-institusi publik merujuk pada kebutuhan psikologis. Lebih lanjut, Perry dan Wise (1990) menunjukkan bahwa jika dibandingkan dengan karyawan di sektor privat, karyawan yang bekerja di sektor publik lebih menitik beratkan pada nilai-nilai penghargaan (reward) intrinsik dan manfaat pekerjaan ketika melayani masyarakat dan kepentingan publik.

Hal itu senada dengan yang dikemukakan Crewson (1997) bahwa PSM adalah orientasi pelayanan seorang individu, minus orientasi ekonomis supaya berguna bagi masyarakat, orientasi untuk menolong orang lain, dan semangat untuk memperoleh prestasi yang bersifat intrinsik atau yang berorientasi pelayanan (service orientation).

Public service motivation (PSM) adalah salah satu bentuk atau bagian yang khas dari motivasi yang dapat di definisikan sebagai motivasi yang mencakup kepercayaan, nilai dan sikap yang melampaui kepentingan pribadi dan kepentingan organisasi, mendorong seorang pekerja atau pegawai untuk berbuat baik kepada orang lain dan menyumbangkan darma baktinya kepada kesejahteraan organisasi dan masyarakat (Perry dan Annie, 2008). Artinya, motivasi pelayanan publik yang positif tentu saja akan melahirkan pekerja atau pegawai yang kompeten dan berdedikasi tinggi terhadap tugas dan kewajibannya, serta dapat meningkatkan prestasi kerja.

Konsep motivasi secara umum merujuk kepada kekuatan yang memberi dorongan, mengarahkan, dan mengekalkan tingkah laku seseorang individu. Sedangkan motivasi pelayanan publik atau PSM adalah salah satu bentuk atau bagian yang khas dari motivasi yang dapat didefinisikan sebagai motivasi yang mencakup kepercayaan, nilai dan sikap yang melampaui kepentingan pribadi dan kepentingan organisasi, mendorong seorang pekerja (pegawai) untuk berbuat baik kepada orang lain dan menyumbangkan darma baktinya kepada kesejahteraan organisasi dan masyarakat. Artinya, konsep PSM menunjukkan bahwa seorang pegawai publik akan terlibat dalam tingkah laku yang 
konsisten terhadap motif yang berorientasikan komunitas dan sikap altruistik.

Menurut Knoke \& Wright-Isak (1982), motif yang dimaksud dibagi atas tiga kategori analisis yang berbeda yaitu: rasional, normatif dan afektif. Motif rasional melibatkan tindakan yang didasarkan pada peningkatan kegunaan individu. Motif normatif merujuk pada tindakan-tindakan yang dihasilkan oleh upaya sesuai dengan norma-norma yang berlaku. Motif afektif merujuk pada perilaku yang didasarkan pada tanggapan emosional atas berbagai konteks sosial.

Dari perspektif afektif, hal ini diklaim bahwa individu tertarik pada pelayanan publik seperti keyakinan tentang pentingnya pelayanan publik. Perspektif normatif menunjukkan daya tarik didasarkan pada alasan etis seperti ekuitas dan keadilan, sedangkan perspektif rasional menunjukkan dasar yang sejalan dengan kepentingan individu untuk tertarik pada pembuatan kebijakan untuk mempromosikan kepentingan publik (Perry \& Wise, 1990).

Salah satu temuan yang paling penting dalam penelitian menyangkut PSM ini adalah hasil penelitian Perry dan Wise terhadap para pegawai sektor publik dan para pekerja sukarela (volunteers) di Amerika Serikat. Kedua sarjana ini telah berhasil memberikan dan mendudukkan definisi atau konsep PSM dan alat ukur yang berbeda dari konsep lain yang berkaitan dengan motivasi pada umumnya. Selain itu, menurut Perry dan Wise, individu yang mempunyai tingkat PSM yang tinggi akan tertarik kepada pekerjaan pelayanan publik karena berbagai sebab, seperti kepentingan diri pribadi, pertimbangan etika, atau peluapan emosi. Mereka berasumsi bahwa PSM berkaitan erat dengan kecenderungan bekerja, prestasi kerja, dan pilihan kerja dari seseorang pegawai publik. Motivasi seorang pegawai publik yang lebih mengutamakan kepentingan orang lain atau kepentingan negara daripada kepentingan diri sendiri.

Berdasarkan atas rangka kerja ini, Keempat dimensi inilah yang pada umumnya terdapat pada para pegawai diberbagai sektor publik. Meskipun terdapat keberagaman definisi PSM, namun dari berbagai definisi tersebut dapat dipahami bahwa motivasi pelayanan publik merupakan motivasi yang bersifat intrinsik yang dimiliki oleh seseorang pegawai dan yang lebih mendahulukan kepentingan orang lain atau negara dari pada kepentingan pribadi.

Empat konsep dimensional tersebut menurut Perry \& Wise (1990) yaitu:

1. Ketertarikan terhadap pembuatan kebijakan publik (attraction to public policy making)

2. Tanggung jawab terhadap kepentingan publik dan kewajiban sebagai warga negara (commitment to public interest and civic duty)

3. Perasaan keharuan atau kasihan (compassion)

4. Sikap pengorbanan diri (self-sacrifice) Secara spesifik, Perry dan Wise (1990) menghipotesiskan 3 hal berkaitan dengan public service motivation yakni:

1. Semakin tinggi PSM yang dimiliki individu, maka semakin besar kemungkinannya bahwa akan menjadi keanggotaan di organisasi sektor public.

2. PSM berhubungan secara positif dengan kinerja individual di organisasi sektor public.

3. Organisasi sektor public yang memiliki anggota dengan PSM yang tinggi akan mengurangi ketergantungannya terhadap penggunaan insentif yang berguna untuk mengelola kinerja organisasional secara efektif.

\subsection{Kepuasan Kerja}

Studi pertama mengenai kepuasan kerja yang berkorelasi dengan motivasi pelayanan publik disampaikan oleh Brewer \& Selden (1998) mengenai whistle blowers di sebuah kantor pemerintahan. Dengan mengandalkan empat pengukuran kepuasan kerja, mereka menemukan bahwa whistle blower sering bertindak sesuai dengan teori motivasi pelayanan publik dan menampilkan motivasi khusus yang dimotivasi oleh kepedulian terhadap kepentingan umum.

Locke dan Lathan (1976) dalam Tella dan Popoola (2007) mengemukakan kepuasan kerja sebagai keadaan emosi menyenangkan atau positif yang dihasilkan dari penilaian pekerjaan dan pengalaman. Kepuasan kerja adalah hasil dari persepsi karyawan tentang seberapa baik pekerjaan mereka sehingga dapat memberikan hal-hal yang dianggap 
penting. Megginson, Mosley, dan Pietri (1982) dalam Ayub dan Rafif (2010) menyatakan bahwa seseorang mengalami kepuasan kerja, ketika mereka merasa baik tentang pekerjaan mereka, perasaan ini sering berhubungan dengan pekerjaan yang mereka lakukan, atau ketika mereka menjadi lebih mahir dalam profesi mereka dan diakui untuk kinerja yang lebih baik.

Schultz (1998) dalam Ayub dan Rafif (2010) berpandangan bahwa kepuasan kerja meliputi perasaan positif dan negatif sikap seseorang tentang pekerjaan mereka dan bukan hanya bergantung pada banyak karakteristik yang berhubungan dengan pekerjaan, namun juga padakarakteristik pribadi, seperti usia, jenis kelamin, kesehatan dan hubungan sosial. Robbins (2002) dalam Rast dan Tourani (2012), kepuasan kerja adalah emosi karyawan yang dapat mempengaruhi perilaku kerja mereka. Hubungan sosial dan faktor psikologis adalah penyebab utama dari kepuasan kerja dan produktivitas pada karyawan.

Kreitnerdan Kinicki (2004) dalam Rast dan Tourani (2012), kepuasan kerja adalah respon afektif dan emosional terhadap berbagai aspek pekerjaan. Jadi secara garis besar kepuasan kerja dapat diartikan sebagai hal yang menyenangkan atau yang tidak menyenangkan seorang pegawai dalam memandang pekerjaannya dan dapat dipengaruhi oleh berbagai macam faktor, baik itu faktor internal maupun faktor eksternal.

Kepuasan kerja merupakan respon afektif atau emosional terhadap berbagai aspek pekerjaan seseorang. Definisi ini berarti kepuasan kerja bukanlah konsep kesatuan. Seseorang dapat relatif puas dengan salah satu aspek dari pekerjaannya dan tidak puas dengan satu atau lebih aspek lainnya (Kreitner \& Kinicki, 2001).

Terdapat lima model utama yang menyebabkan kepuasan kerja:

- Need Fulfillment Model

Model ini mengusulkan bahwa kepuasan ditentukan oleh sejauh mana karakteristik pekerjaan memungkinkan seorang individu untuk memenuhi kebutuhannya. Kebutuhan yang tidak terpenuhi dapat mempengaruhi kepuasan dan turnover. Secara umum diterima bahwa pemenuhan kebutuhan berkorelasi dengan kepuasan kerja.
- Discrepanciest Model

Model ini mengusulkan bahwa kepuasan adalah hasil dari kesesuaian harapan. Kesesuaian harapan merupakan selisih antara apa yang diharapkan seseorang dalam menerima hasil dari pekerjaan (seperti gaji yang baik dan kesempatan promosi) dengan apa yang benar-benar diterima. Ketika harapan lebih besar dari apa yang diterima, seseorang akan merasa tidak puas. Sebaliknya, model ini memprediksi individu akan puas ketika ia mencapai hasil di atas dan di luar harapan. Kesesuaian harapan secara signifikan terkait dengan kepuasan kerja.

- Value Attainment

Ide yang mendasari pencapaian nilai adalah hasil kepuasan dari persepsi bahwa pekerjaan memungkinkan dalam pemenuhan nilai penting pekerjaan individu. Penelitian secara konsisten mendukung prediksi bahwa pemenuhan nilai secara positif berhubungan dengan kepuasan kerja.

- Equity

Dalam model ini, kepuasan merupakan fungsi dari bagaimana keadilan terhadap seorang individu diperlakukan di tempat kerja. Hasil kepuasan dari persepsi seseorang mengenaihasil kerja, berhubungan dengan tenaga yang digunakan, dapat dibandingkan dengan masukan dan hasil penting lainnya. Keadilan dalam gaji dan promosi secara signifikan berkorelasi dengan kepuasan kerja.

- Dispositional/Genetic Components Model

Model ini mencoba untuk menjelaskan poladimana beberapa karyawan tampak puas diberbagai situasi kerja dan beberapa lainnya selalu tampak tidak puas. Model disposisional/genetik didasarkan pada keyakinan bahwa sebagian kepuasan kerja merupakan fungsi dari sifat-sifat pribadi dan faktor genetik. Model ini menunjukkan bahwa perbedaan individu yang stabil sama pentingnya dengan karakteristik lingkungan kerja. faktor genetik juga ditemukan secara signifikan memprediksi kepuasan hidup, kesejahteraan dan kepuasan kerja umum.

\subsection{Kinerja Pegawai}

Pada suatu organisasi, baik organisasi swasta (private sector) maupun organisasi pemerintah (public sector), kinerja atau prestasi kerja pegawai merupakan aspek yang 
sangat penting dalam upaya organisasi mencapai tujuan-tujuannya. Kinerja organisasi tidak dapat dilepaskan dari kinerja para pegawai dalam melaksanakan tugas dan pekerjaannya. Dengan demikian, maju atau tidaknya suatu organisasi sangat ditentukan oleh peran dan kualitas para pegawainya. Secara umum kinerja sering diartikan sebagai kemampuan untuk menghasilkan sesuatu hasil.

Kurniawan (2005) menyatakan bahwa kinerja merupakan penilaian atas kualitas pengelolaan dan kualitas pelaksanaan tugas atau operasi organisasi. Simamora (2004) menyatakan bahwa kinerja adalah tingkat kerja yang dicapai oleh seseorang dengan syaratsyarat yang telah ditentukan. Menurut Pasolong (2010) konsep kinerja pada dasarnya dapat dilihat dari dua segi, yaitu kinerja pegawai (individu) dan kinerja organisasi. Kinerja pegawai adalah hasil kerja perseorangan dalam suatu organisasi. Sedangkan kinerja organisasi adalah totalitas hasil kerja yang dicapai suatu organisasi. Kinerja pegawai dan kinerja organisasi memiliki keterkaitan yang sangat erat. Tercapainya tujuan organisasi tidak bisa terlepas dari sumberdaya yang dimiliki oleh organisasi yang digerakkan atau dijalankan pegawai yang berperan aktif sebagai pelaku dalam upaya mencapai tujuan organisasi tersebut, dalam penelitian ini yang akan dilihat adalah kinerja pegawai.

Disamping teori tersebut Rivai (2004) menyebutkan: "kinerja adalah kesediaan seseorang atau kelompok orang untuk melakukan sesuatu kegiatan dan menyempurnakannya sesuai dengan tanggung jawabnya dengan hasil seperti yang diharapkan". Pada hakikatnya kinerja merupakan prestasi yang dicapai oleh seseorang dalam melaksanakan tugasnya atau pekerjaannya sesuai dengan standar dan kriteria yang ditetapkan untuk pekerjaan itu".Oleh karenanya, kinerja merupakan hal yang penting untuk dilakukan secara berkelanjutan dan memberikan umpan balik dalam upaya mencapai keberhasilan di masa mendatang.

Pada dasarnya pengertian kinerja dapat dimaknai secara beragam. Beberapa pakar memandangnya sebagai hasil dari suatu proses penyelesaian pekerjaan, sementara sebagian yang lain memahaminya sebagai perilaku yang diperlukan untuk mencapai hasil yang diinginkan. Agar terdapat kejelasan mengenai kinerja, akan disampaikan beberapa pengertian mengenai kinerja.

Kinerja menurut Wood et al (2001) merupakan suatu pengukuran ringkas dari kuantitas dan kualitas kontribusi tugas-tugas yang dilakukan oleh individu atau kelompok untuk kerja unit atau organisasi. Kinerja adalah tingkat keberhasilan dalam melaksanakan tugas dan kemampuan untuk mencapai tujuan yang telah ditetapkan, Gibson et al (1997). Konsep kinerja merujuk kepada tingkat pencapaian pegawai atau organisasi terhadap persyaratan pekerjaan. Mathis \& Jackson (2004) mendefinisikan kinerja merupakan prestasi atau pencapaian hasil kerja yang dicapai pegawai berdasarkan standar dan ukuran penilian yang telah ditetapkan.

\subsection{Penilaian Kinerja Pegawai}

Kinerja pegawai dalam periode waktu tertentu perlu dievaluasi atau dinilai karena penilaian terhadap kinerja pegawai merupakan bagian dari proses staffing, yang dimulai dari proses rekrutmen, seleksi, orientasi, penempatan, pelatihan dan proses penilaian kerja (Syafaruddin, 2001). Kenyataan dewasa ini menunjukkan masih relatif banyak organisasi atau perusahaan mengabaikan fungsi penilaian terhadap kinerja. Padahal penilaian terhadap kinerja merupakan bagian yang sangat penting dari manajemen kinerja dan mungkin juga sistem penilaian yang diterapkan tidak sesuai dengan kultur organisasi yang dikembangkan sehingga tidak mendorong motivasi kerja. Hal ini mengakibatkan adanya proses penilaian kinerja yang cenderung bersifat administratif, subjektif dan kurang memiliki daya pembeda yang valid.

Organisasi yang membangun kemampuan bersaing melalui sumber daya manusia sebagai keunggulan kompetitif maka sistem penilaian terhadap kinerja pegawai dalam organisasi harus memiliki daya pembeda untuk menentukan pegawai berprestasi, yang pantas menerima insentif dan yang potensial untuk dikembangkan. Hal ini menunjukkan bahwa penilaian terhadap kinerja haruslah dipandang sebagai kegiatan strategis organisasi untuk 
mendorong kinerja, pengembangan, melindungi hak-hak (berupa kompensasi), dan pengukuran terhadap kewajiban serta tanggung jawab pegawai dalam menunaikan tugastugasnya. Dari hasil penilaian terhadap kinerja ini pihak pimpinan organisasi akan mengetahui kinerja karyawan yang telah dicapai dalam periode waktu tertentu. Oleh karena itu, setiap organisasi wajib memiliki manajemen kinerja sebagai bagian sentral untuk keunggulan bersaing melalui peran sumber daya manusia dan menjalankan strategi bisnis yang berorientasi pada kebutuhan pelanggan. Mondy \& Noe (1996) mengatakan bahwa model manajemen kinerja dalam organisasi melibatkan empat faktor interdependen sifatnya, yaitu (1) atribut individual, (2) strategi organisasi (3) hambatan situasional dan (4) tujuan yang ingin dicapai.

Penilaian kinerja merupakan proses yang harus dilakukan dalam mengevaluasi kinerja karyawan. Penilaian kinerja dapat dilakukan oleh beragam pihak, yaitu oleh rekan kerja, atasan langsung maupun oleh karyawan itu sendiri. Penilaian kinerja (performance appraisal) adalah proses evaluasi seberapa baik karyawan mengerjakan pekerjaannya, ketika dibandingkan dengan satu set standar dan kemudian mengkomunikasikannya dengan para karyawan (Martoyo, 2007). Menurut Simamora (2004) penilaian kinerja adalah proses yang dipakai oleh organisasi untuk mengevaluasi pelaksanaan kerja individu karyawan.

Menurut Mathis dan Jackson (2004) penilaian kinerja (performance appraisal) adalah proses evaluasi seberapa baik karyawan mengerjakan pekerjaan mereka ketika dibandingkan dengan satu set standar dan kemudian mengkomunikasikan informasi tersebut.

Menurut pendapat Wether dan Davis (Suwanto dan Donni, 2011), penilaian kinerja memiliki beberapa tujuan dan manfaat antara lain adalah:

1. Performance Improvement, memungkinkan pegawai dan manajer untuk mengambil tindakan yang berhubungan dengan peningkatan kinerja.

2. Compensation Adjustment, membantu para pengambil keputusan untuk menentukan siapa saja yang berhak menerima kenaikan gaji atau sebaliknya.

3. Placement Decision, menentukan promosi, transfer, dan demotion (penurunan pangkat).

4. Training and Development Needs, mengevaluasi kebutuhan pelatihan dan pengembangan bagi pegawai agar kinerja mereka lebih optimal.

5. Career Planning and Development, memandu untuk menentukan jenis karier dan potensi karier yang dapat dicapai.
6. Staffing
Process
Deficiencies, mempengaruhi prosedur perekrutan pegawai.

7. Equal Employment Opportunity, menunjukkan bahwa placement decision tidak diskriminatif.

8. External Challenges, kadang-kadang kinerja pegawai dipengaruhi oleh faktor eksternal seperti keluarga, keuangan pribadi, kesehatan, dan lain-lainnya. Biasanya faktor ini tidak terlalu kelihatan, namun dengan melakukan penilaian kinerja, faktor-faktor eksternal ini akan kelihatan sehingga membantu departemen sumber daya manusia untuk memberikan bantuan bagi peningkatan kinerja pegawai.

9. Feedback, memberikan umpan balik bagi urusan kepegawaian maupun bagi pegawai itu sendiri.

Menurut Moeheriono (2009) dalam Rachmawati (2012) mengemukakan bahwa pengukuran kinerja pegawai non PNS dapat ditinjau dari beberapa aspek yakni:

1. Pengetahuan mengenai pekerjaan yakni berkaitan dengan pemahaman mengenai tugas dan tanggungjawab, memiliki pengetahuan, prosedur dan keahlian teknis, menggunakan informasi peralatan dan teknik dengan tepat dan benar serta mengikuti perkembangan peraturan dan prosedur teknis yang terbaru.

2. Kualitas kerja yakni mengenai perhatian, detail, akurat, cermat dan teliti pegawai atas pekerjaan yang dikerjakan.

3. Adaptasi dan fleksibilitas yakni menyesuaikan diri dengan segala perubahan dalam lingkungan kerja, menunjukkan hasil kerja yang baik meskipun dibawah tekanan dan mempelajari dan menguasai informasi peraturan dan prosedur yang terbaru. 
4. Kerjasama yakni memelihara hubungan kerja yang efektif, dapat bekerja sama dengan tim, memberikan bantuan dan dukungan kepada orang lain, mengakui kesalahan sendiri dan mau belajar dari kesalahan tersebut.

5. Tanggungjawab yakni hadir secara rutin dan tepat waktu, mengikuti instruksiinstruksi yang berikan, bekerja secara mandiri, menyelesaikan tugas dan tanggungjawab sesuai dengan batas waktu yang ditentukan.

Pengukuran kinerja merupakan alat untuk menilai kesuksesan organisasi, dalam konteks organisasi sektor publik, kesuksesan organisasi itu akan digunakan untuk mendapatkan legitimasi dan dukungan publik. Masyarakat akan menilai kesuksesan organisasi sektor publik melalui kemampuan organisasi dalam memberikan pelayanan publik yang relatif murah dan berkualitas. Pelayanan publik tersebut yang menjadi bottom line dalam organisasi sektor publik, beberapa negara maju menggunakan strategi dan pendekatan yang berbeda untuk memberikan pelayanan terbaik baik warganya (Kurniawan, 2005).

\subsection{Pengembangan Hipotesis}

\section{Public Service Motivation dan Kinerja}

Individu dengan motivasi layanan publik yang lebih besar cenderung berkinerja lebih baik dalam pekerjaan sektor publik. Pekerjaan sektor publik, dicirikan oleh atribut-atribut seperti signifikansi tugas tinggi dan memberi pelayanan public (Perry \& Wise, 1990). Public service motivation secara signifikan berhubungan positif dengan kinerja (Nicola, 2015).

H1: Public Service Motivation berpengaruh signifikan terhadap kinerja pegawai

\section{Kepuasan Kerja dan Kinerja}

Kepuasan kerja adalah sikap emosional atau perasaan yang menyenangkan dan mencintai pekerjaannya. Sikap ini dicerminkan oleh moral kerja, kedisiplinan, dan prestasi kerja. Kepuasan kerja dinikmati dalam pekerjaan, luar pekerjaan, dan kombinasi dalam dan luar pekerjaan (Hasibuan, 2009). Kinerja karyawan dikatakan baik, apabila kepuasan kerja yang dirasakan oleh karyawan juga semakin baik. Dengan kata lain, kinerja karyawan yang baik dapat dipengaruhi kepuasan kerja pada diri karyawan. Dengan demikian kepuasan kerja dalam suatu perusahaan sangat dibutuhkan untuk mendongkrak kinerja karyawan. Kepuasan kerja dapat diperoleh berupa gaji pokok, kompensasi, peluang kenaikan gaji, peluang promosi jabatan, penghargaan, perjalanan ke luar negeri, hubungan kerja, dan lainnya.

Hasil penelitian ini didukung oleh penelitian Ali, Idris dan Kalalinggi (2013) yang menunjukkan bahwa kepuasan kerja berpengaruh secara signifikan dan positif terhadap kinerja karyawan. Penelitian Ali, Idris dan Kalalinggi (2013) senada dengan penelitian yang dilakukan oleh Rosita dan Yuniati (2016) serta Febriyana (2015) yang juga menunjukkan hasil yaitu kepuasan kerja berpengaruh secara signifikan dan positif terhadap kinerja karyawan.

Kepuasan kerja secara signifikan berhubungan positif dengan kinerja (Weihui, 2013). Kepuasan karyawan tidak secara otomatis dapat meningkatkan produktivitas, walaupun ketidakpuasan karyawan cenderung menurunkan produktivitas lebih sering mangkir dan menghasilkan kualitas lebih rendah dari pada karyawan yang puas (Ivancevich, 2008).

H2: Kepuasan kerja berpengaruh signifikan terhadap kinerja pegawai

\section{Metode Penelitian}

Penelitian ini dilaksanakan di kantor Capil Konawe Selatan. Pada penelitian ini sampel penelitian adalah seluruh pegawai PNS dan Non PNS pada kantor Capil Kabupaten Konawe Selatan yakni sebanyak 65 pegawai, dengan demikian maka seluruh populasi dijadikan responden dalam penelitian ini. Pengukuran data yang digunakan dalam penelitian ini adalah menggunakan skala likert. Metode analisis data yang digunakan adalah analisis regresi linear berganda.

Berdasarkan hasil uji validitas dan reliabilitas data diuraikan bahwa pengukuran variabel public service motivation terdiri atas 4 item pernyataan yang diadopsi dari pendapat Perry \& Wise (1990), kepuasan kerja terdiri atas 5 item pernyataan yang diadopsi dari pendapat Javed, Balouch \& Hassan (2014) dan kinerja pegawai terdiri dari 5 item pernyataan 
yang diadopsi dari pendapat Rachmawati (2012).

\section{Hasil Penelitian dan Pembahasan}

Hasil output dari analisis regresi, secara lebih jelasnya dapat terlihat pada tabel berikut:

Tabel 1. Hasil Estimasi Regresi Linear

Berganda

\begin{tabular}{lrrrr}
\hline \multicolumn{1}{c}{ Model } & \multicolumn{4}{c}{ Unstandardized } \\
& Coefficients & & \\
& $\mathrm{B}$ & Std. Error & \multicolumn{1}{c}{$\mathrm{t}$} & \multicolumn{1}{c}{ Sig. } \\
\hline 1 (Constant) & .173 & .096 & 1.805 & .080 \\
Public Service & .699 & .036 & 19.493 & .000 \\
Motivation & .699 & .035 & 7.442 & .000 \\
\hline Kepuasan Kerja & .263 & .032 &
\end{tabular}

\section{Pengaruh Public Service Motivation terhadap Kinerja Pegawai}

Berdasarkan hasil penelitian yang telah diuraikan sebelumnya yakni mengenai pengaruh public service motivation terhadap kinerja pegawai pada kantor Capil Konawe Selatan, ditemukan bahwa public service motivation berpengaruh positif signifikan terhadap kinerja pegawai pada kantor Capil Konawe Selatan. Adanya pengaruh positif signifikan tersebut, mengindikasikan peran penting bagi pegawai sektor publik dalam kepemilikan public service motivation sebagai variabel dalam menunjang peningkatan kinerja pegawai.

Crewson (1997) dalam Trisni (2016) mengemukakan bahwa kepemilikan public service motivation tergolong penting untuk dimiliki oleh pegawai, yang akan bekerja pada organisasi publik. Hal ini dikarenakan adanya kecenderungan yang dimiliki dari pegawai untuk berorientasi pada melayani individu, minus orientasi ekonomis guna berguna bagi masyarakat, orientasi untuk menolong orang lain dan semangat untuk memperoleh prestasi yang bersifat intrinsic atua yang berorientasi melayani.

Brewer (2000) yang mengungkapkan bahwa sebagian individu memiliki norma dan emosi yang kuat untuk mengabdi pada sektor publik. Motivasi atau etika melayani publik ini dipandang dapat menarik individu-individu tertentu untuk mengabdi di sektor publik dan membantu mewujudkan perilaku kerja (work behavior) yang konsisten dengan kepentingan publik.
Terdapat tiga katergori dalam Public Service Motivation yang dikemukakan oleh Knoke dan Wright-Isak dalam Perry dan Wise (1990) yaitu motif rational, norm-based, dan affective. Motif rasional didasarkan pada individual utility maximization, yaitu bahwa individu tertarik untuk bekerja di sektor publik karena memiliki kepentingan untuk mendukung sektor privat tertentu ketika ia memiliki kewenangan atau andil dalam perumusan kebijakan publik. Motif normatif didasarkan ada suatu keinginan untuk melayani kepentingan publik, loyalitas terhadap tugas dan pemerintah. Sedangkan motif afektif didasarkan pada faktor emosional, yaitu komitmen terhadap sebuah program yang didasarkan atas suatu keyakinan mengenai manfaat sosialnya dan rasa patriotisme.

Kusuma dan Wahyu (2014) mengemukakan bahwa individu dengan motivasi layanan publik yang lebih besar cenderung berkinerja lebih baik dalam pekerjaan sektor publik. Pekerjaan sektor publik, dicirikan oleh atributatribut seperti signifikansi tugas tinggi dan memberi pelayanan public. Public service motivation secara signifikan berhubungan positif dengan kinerja (Nicola, 2015).

Hasil penelitian serupa dikemukakan pula oleh Lewis dan Alonso dalam Komalasari, dkk (2009) yang menyimpulkan adanya hubungan positif antara motivasi pelayanan publik dan kinerja pegawai. Menurut mereka, ketika motivasi yang dimiliki oleh pegawai adalah motivasi yang bersifat intrinsik, maka kinerja mereka sudah pasti naik. Houston dalam Vera (2015), berpendapat bahwa pegawai di sektor publik banyak termotivasi oleh ganjaran kerja yang bersifat intrinsik dibanding ganjaran bersifat ekstrinsik. Hal ini berarti para pegawai organisasi publik dalam bekerja lebih termotivasi oleh kepedulian kepada masyarakat dan keinginan untuk kepentingan publik, bukan untuk kepentingan pribadi saja.

Van Loon (2015) menunjukkan bahwa banyak karyawan publik juga merasa perlu untuk berkontribusi kepada masyarakat melalui pekerjaan mereka, dan bahwa kinerja mereka sebagian tergantung pada apakah mereka menganggap bahwa mereka mampu memberikan kontribusi kepada masyarakat. Xiaohua (2008), salah satu faktor yang 
mempengaruhi kinerja adalah public service motivation (PSM). Public service motivation (PSM) merupakan suatu kecenderungan seseorang untuk ikut bertanggungjawab terhadap motif yang tertanam secara mendalam dan secara unik pada institusi publik. Sehingga, karyawan dengan motivasi melayani publik yang tinggi cenderung akan memiliki kepuasan kerja yang tinggi pula, dan pada akhirnya berkinerja tinggi. Selain itu, karyawan dengan motivasi melayani publik yang tinggi, juga diharapkan memiliki komitmen kepada organisasi yang tinggi, cenderung akan memiliki kepuasan kerja yang tinggi dan pada akhirnya berkinerja tinggi.

\section{Pengaruh Kepuasan Kerja terhadap Kinerja Pegawai}

Berdasarkan hasil penelitian yang telah diuraikan sebelumnya yakni mengenai pengaruh kepuasan kerja terhadap kinerja pegawai pada kantor Capil Konawe Selatan, ditemukan bahwa kepuasan kerja berpengaruh positif signifikan terhadap kinerja pegawai pada kantor Capil Konawe Selatan. Adanya pengaruh positif signifikan tersebut, mengindikasikan bahwa peningkatan hasil kerja seorang pegawai dalam melaksanakan tugas dan tanggungjawabnya, sangat bergantung dengan tingginya kepuasan kerja dari seorang pegawai itu sendiri. Semakin tinggi kepuasan kerja yang dirasakan oleh seorang pegawai dalam bekerja, maka semakin tinggi pula pencapaian kinerja kerja pegawai.

Kepuasan kerja adalah sikap emosional atau perasaan yang menyenangkan dan mencintai pekerjaannya. Sikap ini dicerminkan oleh moral kerja, kedisiplinan, dan prestasi kerja. Kepuasan kerja dinikmati dalam pekerjaan, luar pekerjaan, dan kombinasi dalam dan luar pekerjaan (Hasibuan, 2009). Kinerja karyawan dikatakan baik, apabila kepuasan kerja yang dirasakan oleh karyawan juga semakin baik. Dengan kata lain, kinerja karyawan yang baik dapat dipengaruhi kepuasan kerja pada diri karyawan. Dengan demikian kepuasan kerja dalam suatu perusahaan sangat dibutuhkan untuk mendongkrak kinerja karyawan. Kepuasan kerja dapat diperoleh berupa gaji pokok, kompensasi, peluang kenaikan gaji, peluang promosi jabatan, penghargaan, perjalanan ke luar negeri, hubungan kerja, dan lainnya.

Megginson, Mosley, dan Pietri (1982) dalam Ayub dan Rafif (2010) menyatakan bahwa seseorang mengalami kepuasan kerja, ketika mereka merasa baik tentang pekerjaan mereka, perasaan ini sering berhubungan dengan pekerjaan yang mereka lakukan, atau ketika mereka menjadi lebih mahir dalam profesi mereka dan diakui untuk kinerja yang lebih baik.

Hasil penelitian ini didukung oleh penelitian Ali, Idris dan Kalalinggi (2013) yang menunjukkan bahwa kepuasan kerja berpengaruh secara signifikan dan positif terhadap kinerja karyawan. Penelitian Ali, Idris dan Kalalinggi (2013) senada dengan penelitian yang dilakukan oleh Rosita dan Yuniati (2016) serta Febriyana (2015) yang juga menunjukkan hasil yaitu kepuasan kerja berpengaruh secara signifikan dan positif terhadap kinerja karyawan.

Kepuasan kerja secara signifikan berhubungan positif dengan kinerja (Weihui, 2013). Kepuasan karyawan tidak secara otomatis dapat meningkatkan produktivitas, walaupun ketidakpuasan karyawan cenderung menurunkan produktivitas lebih sering mangkir dan menghasilkan kualitas lebih rendah dari pada karyawan yang puas (Ivancevich, 2008).

Robbins dan Judge (2013) mengemukakan bahwa ada konsekuensi ketika karyawan menyukai pekerjaan mereka, dan ada konsekuensi ketika karyawan tidak menyukai pekerjaan mereka. Robbins (2006) juga menyatakan menganai dampak kepuasan kerja pada kinerja karyawan. Karyawan yang merasa puas akan pekerjaannya memiliki kemungkinan yang lebih besar untuk membicarakan hal-hal positif tentang organisasinya, membantu yang lain, dan berbuat kinerja pekerjaan mereka melampaui perkiraan normal.

\section{Kesimpulan}

Kesimpulan pada penelitian yakni public service motivation secara parsial berpengaruh positif signifikan terhadap kinerja pegawai pada kantor Capil Kota Kendari. Hal ini berarti bahwa kinerja pegawai yang lebih baik dapat ditingkatkan dengan adanya peranan public 
service motivation. Ditemukan pula bahwa kepuasan kerja secara parsial berpengaruh positif signifikan terhadap kinerja pegawai pada kantor Capil Kota Kendari. Hal ini dapat disimpulkan bahwa kinerja pegawai yang lebih baik dapat ditingkatkan dengan adanya peranan kepuasan kerja pegawai.

\section{Daftar Pustaka}

Ali, M., Idris, A., \& Kalalinggi, R. (2013). Pengaruh kepuasan kerja terhadap kinerja pegawai pada badan ketahanan pangan dan pelaksana penyuluhan daerah kota samarinda. eJournal Administrative Reform, 1(2), 418-430.

Ayub, N., \& Rafif, S. (2010). The Relationship Between Work Motivation and Job Satisfaction. Pakistan Business Review, 322-347.

Brewer \& Selden (1998). Public Service Motivation and Commitment. Sage Journal, 4(1).

Crewson, P.E. (1997). Public Service Motivation: Building Empirical Evidence of Incidence and E Ect. Journal of Public Administration Research and Theory, (4).

Elsiyana, D. (2014). Pengaruh Public Service Motivation terhadap Kinerja Pegawai dengan Organizational Citizenship Behavior dan Kepuasan kerja sebagai Variabel Intervening pada pegawai Pemerintah. Skripsi Universitas Islam Indonesia, Fakultas Ekonomi, Yogyakarta.

Febriyana, W. (2015). Pengaruh kepuasan kerja terhadap kinerja karyawan PT Kabepe Chakra 2015. e-Proceeding of Management, 2(3), 2954-2961.

Gibson, J. L., Ivancevich, J. M., \& Donelly, J. H. (1997). Organisasi, Perilaku, Struktur dan Proses. Jakarta: Erlangga.

Hasibuan, M. S. P. (2009). Manajemen Sumber Daya Manusia, Jakarta. Bumi Aksara.

Ivancevich, J. M. (2008). Perilaku dan Manajemen Organisasi, Jilid 1 dan 2 Jakarta: Erlangga.

Kim, S. (2004). Public service motivation and organizational citizenship behavior in Korea. Journal of Public Administration, 27(8), 722-740.

Komalasari, P. T. T., Nasih, M., \& Prasetio, T. (2009). Pengaruh Public Service Motivation
Dan Organizational Citizenship Behavior Terhadap Kinerja Organisasi Pemerintahan. Jurnal Manajemen Teori dan Terapan, 2(2).

Knoke \& Wright-Isak (1982). Measuring Public Service Motivation: An Assessment of Construct Reliability and Validity. Journal of Public Administration Research and Theory: J-PART, 6(1).

Kurniawan, A. (2005). Transformasi Pelayanan Publik. Pembaharuan. Yogyakarta.

Kusuma, A., \& Wahyu, R. (2014). Pengaruh Public Service Motivation Terhadap Kinerja Pegawai. Skripsi Universitas Negeri Yogyakarta.

Martoyo, S. (2007). Manajemen Sumber Daya Manusia, $\downarrow$ Edisi 5, Cetakan Pertama. Yogyakarta. BPFE.

Mathis, R. L., \& Jackson, J. H. (2004). Human Resource Management: Manajemen Sumber Daya Manusia. Terjemahan Dian Angelia. Salemba Empat. Jakarta.

Moeheriono. (2009). Pengukuran Kinerja Berbasis Kompetensi: Competency Based Human Resource Management. Jakarta. Ghalia Indonesia.

Mondy \& Noe. (1996). Human Resources Management. Prentice Hall, Texas.

Nicola, B. (2012). Experimental Evidence on the Relationship between Public Service Motivation and Job Performance. Public Administration Review, Vol. 73, Iss. 1, pp. 143-153.

Parvin, M. M., \& Kabir, M. M. N. (2011). Actors Affecting Employee Job Ssatisfaction of Pharmaceutical Sector. Australian Journal of Business and Management Research. 1(9), 113-123.

Pasolong, H. (2010). Teori Administrasi Publik, Alfabeta, Bandung.

Perry, J. L., \& Annie, H. (2008). Motivation In Public Management: The Call of Public Service. Oxford University press. Oxford.

Perry, J. L., \& Wise. (1990). Measuring public service motivation: An assessment of construct reliability and validity. Journal of Public Administration Research and Theory, (1), 5-22.

Rachmawati, I. (2012). Faktor-Faktor yang Berhubungan dengan Kinerja Pegawai Non 
PNS di RSUD Kota Bekasi Tahun 2012. Fakultas Kesehatan Masyarakat. Depok.

Rast, S., \& Tourani, A. (2012). Evaluation of Employees' Job Satisfaction and Role of Gender Difference: An Empirical Study at Airline Industry in Iran. International Journal of Business and Social Science, 3(7).

Rivai, V. (2004). Manajemen Sumber Daya Manusia Untuk Perusahaan. PT. Raja Grafindo Persada. Jakarta.

Rosita, T., \& Yuniati, T. (2016). Pengaruh kepuasan kerja terhadap kinerja karyawan dengan komitmen organisasional sebagai variabel intervening. Jurnal Ilmu \& Riset Manajemen, 5(1), 1-20.

Simamora, H. (2004). Manajemen Sumber Daya Manusia. STIE YKPN, Yogyakarta.

Suwanto, H. P., \& Donni J. (2011). Manajemen SDM dalam Organisasi Publik dan Bisnis. Alfabeta, Bandung.

Syafaruddin, A. (2001). Manajemen Sumber Daya Manusia, Strategi Keunggulan Kompetitif. BPFE UGM, Yogyakarta.

Tella, A. A., \& Popoola S. O. (2007). Work Motivation, Job Satisfaction, and Organisational Commitment of Library Personnel in Academic and Research Libraries in Oyo State, Nigeria. Library Philosophy and Practice, 1-16.
Trisni, W. (2016). Pengaruh Public Service Motivation Terhadap Kinerja Pegawai Melalui Kepuasan Kerja Pegawai di Puskesmas Rawat Inap Kota Yogyakarta. Universitas Muhammadiyah Yogyakarta.

Van Loon (2015). The Motivational Bases of Public Service. Public Administration Review 50 (May/June) : 367373.

Vera, Z. P. (2015). Public Service Motivation (PSM) Pegawai pada Kantor Kecamatan Toapaya Kabupaten Bintan. Program Studi Ilmu Administrasi Negara Fakultas Ilmu Sosial Dan Politik, Universitas Maritim Raja Ali Haji. Tanjungpinang.

Weihui, (2013). The Impact of Caring Climate, Job Satisfaction, and Organizational Commitment on Job Performance of Employees in a China's Insurance Company. Journal of Business Ethics, 124(2):339-349.

Wood, J., Wallace, J. P., Zeffane, R., Schermerhorn, J., Hunt, J. B., \& Osborne, R. H. (2001). Organisational Behaviour An Asia-Pacific Perspective. John Wiley \& Sons. Singapore.

Xiaohua (2008). Measuring Public Services Motivation: An Assessment of Construct Realibility and Validity. Journal of Public Administration Research and Theory (JPART). 6(1). pp 5-23. 